\title{
ACRL List of Materials Available
}

May 1978

Unless otherwise noted, single copies of ACRL materials are available to members of the Association of College and Research Libraries free of charge and to nonmembers for $\$ 1$ each from: ACRL Office, $50 \mathrm{E}$. Huron St., Chicago, IL 60611; (312) 944-6780. All orders should include a self-addressed mailing label and $26 \%$ in postage.

Payment must accompany orders. Make checks payable to American Library Association.

\section{STANDARDS AND GUIDELINES}

Standards for College Libraries. (C\&RL News, October 1975)

College Library Standards: Questions and Answers. (C\&RL News, November 1974).

Guidelines for Two-Year College Learning Resources Programs. Association of College and Research Libraries/American Association of Community and Junior Colleges/Association for Educational Communications and Technology. (C\&RL News, December 1972).

Guidelines for Bibliographic Instruction in Academic Libraries. (C\&RL News, April 1977).

Access Policy Guidelines. (C\&RL News, November 1975).

Guide to Methods of Library Evaluation. (C\&RL News, October 1968).

Guidelines for Branch Libraries in Colleges and Universities. (CURL News, October 1975).

Guidelines for Library Services to Extension Students. (ALA Bulletin, January 1967).

\section{FaCUlTy Status and GovernaNCE}

Faculty Status for Academic Librarians; A History and Policy Statements. ACRL Committee on Academic Status, comp. (1975) \$3.50. Order from Order Department, American Library Association, 50 E. Huron St., Chicago, IL 60611. Payment must accompany order.

Standards for Faculty Status for College and University Librarians. (C\&RL News, May 1974).

Joint Statement on Faculty Status of College and University Librarians. Association of College and Research Libraries/American Association of University Professors/Association of American Colleges. (C\&RL News, February 1974).

Model Statement of Criteria and Procedures for Appointment, Promotion in Academic Rank, and Tenure for College and University Librarians. (C\&RL News, September 1973 and October 1973, with a revision by the ACRL Board of Directors).

Guidelines and Procedures for the Screening and Appointment of Academic Librarians. (CURL News, September 1977).
Statement on the Terminal Professional Degree for Academic Librarians. (1975).

Statement on Collective Bargaining. (1975).

Salary Structures of Librarians in Higher Education for the Academic Year 1975-76. Richard J. Talbot and Ann von der Lippe. (1976) \$2.50. Order from ACRL Office. Payment must accompany orders.

\section{MANUSCRIPTS AND ARCHIVES}

Guidelines on Manuscripts and Archives. Compilation of policy statements prepared by the ACRL Rare Books and Manuscripts Section Committee on Manuscripts Collections. Contains: Introduction by Clyde C. Walton; Statement on Appraisal of Gifts; Statement on Legal Title; Statement on Access to Original Research Materials in Libraries, Archives, and Manuscript Repositories; Statement on the Reproduction of Manuscripts and Archives for Noncommercial Purposes; Statement on the Reproduction of Manuscripts and Archives for Commercial Purposes; and Universal Gift Form and Instructions. (1977).

\section{OTHER}

How to Participate in ACRL. (C \&RL News, January 1978).

Guidelines for ACRL Chapters. (CURL News, March 1975).

Eighteenth-Century English Books-Considered by Librarians and Booksellers, Bibliographers and Collectors. Hendrik Edelman, ed. Proceedings of a preconference sponsored by the ACRL Rare Books and Manuscripts Section, June 25-28, 1975, San Francisco. (1976) \$5.00. Order from ACRL Office. Payment must accompany orders.

Networks and the University Library. LeMoyne W. Anderson, ed. Proceedings of a preconference sponsored by the ACRL University Libraries Section, June 21-23, 1973, Las Vegas. (1974) $\$ 3.00$ Order from ACRL Office. Payment must accompany orders.

Problems with Evaluating Library Instruction. Panel discussion from the 6th annual Conference on Library Orientation for Academic Libraries, May 13-14, 1976, Eastern Michigan University. Audiocassette, 60 minutes. (1976) \$6.50. Order from ACRL Office. Payment must accompany orders.

Items listed on the next page are not available from the ACRL Office. Orders and inquiries should be sent directly to the address or agency listed for each entry. 


\section{College \& Research Libraries}

Official journal of the Association of College and Research Libraries. Published seventeen times/year: six bimonthly journal issues and eleven monthly (July/August combined) news issues.

Editor: Richard D. Johnson, Director of Libraries, James M. Milne Library, State University College, Oneonta, NY 13820. News Editor: John V. Crowley, Assistant Director, James M. Milne Library, State University College, Oneonta, NY 13820.

Sent to ACRL members as a perquisite of membership. Also available on subscription, $\$ 25 /$ year. Order from Subscription Department, American Library Association, $50 \mathrm{E}$. Huron St., Chicago, IL 60611; (312) 944-6780.

\section{CHOICE}

Current book selection guide for undergraduate library collections. Published monthly, eleven times/year (July/August combined).

Editor: Louis A. Sasso, Editor, Choice, 100 Riverview Center, Middletown, CT 06457.

Subscription price, \$40/year. Single copies, \$4. Annual cumulated index, $\$ 5$ as a separate. Order from: Subscription Department, Choice, 100 Riverview Center, Middletown, CT 06457; (203) 347-6933.

Choice Reviews-on-Cards. All reviews from regular issues of Choice reprinted on individual 3-by-5-inch cards. Monthly issues, eleven times/year (July/August combined). Subscriptions, $\$ 120.00 /$ year, available only to subscribers of Choice. Order from Subscription Department, Choice.

Choice: A Classified Cumulation; Volumes 1-10, March 1964-February 1974. Edited by Richard K. Gardner and Phyllis Grumm; assisted by Julia Johnson. (1976-77) 9 volumes, $\$ 395.00$. Index (vol.9), $\$ 49.50$ as a separate. Order from Rowman and Littlefield, 81 Adams Dr., Totowa, NJ 07512.

Building a Children's Literature Collection. "A Suggested Basic Reference Collection for Academic Libraries" by Harriet B. Quimby and Clara O. Jackson, and "A Suggested Basic Collection of Children's Books" by Rosemary Weber. (Choice Bibliographical Essay Series, no.3) (1975) \$3.95. Order from Choice.

Maritime History; A Basic Bibliography. Edward W. Sloan III. (Choice Bibliographical Essay Series, no. 1) (1973) \$2.00. Order from Choice.

Opening Day Collection. 3d ed. Richard K. Gardner, ed. (1974) \$7.50. Order from Choice.

Southeast Asia; Bibliographic Directions in a Complex Area. Paul Bixler. (Choice Bibliographical Essay Series, no.2) (1974) $\$ 4.75$ Order from Choice.

Vocational-Technical Periodicals for Community College Libraries. Rev. ed. ACRL Community and Junior College Libraries Section Bibliogra- phy Committee. (Choice Bibliographical Essay Series, no.4) (1976) \$6.95. Order from Choice.

\section{COLleCtion DEVELOPMENT}

Books for College Libraries. 2d ed. (1975) 6 volumes, $\$ 65.00$. Single volumes, $\$ 12.50$ each. Vol. I, Humanities; Vol.2, Language and Literature; Vol.3, History; Vol.4, Social Sciences; Vol 5, Psychology, Science, Technology, and Bibliography; Vol.6, Author, Title, and Subject Indexes. Order from Order Department, American Library Association, 50 E. Huron St., Chicago, IL 60611 .

Books for Junior College Libraries. James W Pirie, comp. (1969) $\$ 35.00$. Order from Order Department, American Library Association, 50 E. Huron St., Chicago, IL 60611 .

\section{ACRL PUBlications IN LibrarLanship}

Monographic series, published irregularly. Numbers 1-33, ACRL Monograph Series.

Editor: Joe W. Kraus, Director of Libraries, Illinois State University, Normal, IL 61761.

Available on standing order or as single volumes. Order from Order Department, American Library Association, $50 \mathrm{E}$. Huron St., Chicago, IL 60611

Out-of-print titles are available from University Microfilms, Inc., $300 \mathrm{~N}$. Zeeb Rd., Ann Arbor, MI 48106 .

\section{Titles in Print}

No. 29-The Career of the Academic Librarian: A Study of the Social Origins, Educational Attainments, Vocational Experience, and Personality Characteristics of a Group of American Academic Librarians. Perry D. Morrison. (1969) \$4.50

No.30-Junior College Libraries: Development, Needs, and Perspectives. Everett LeRoy Moore, ed. (1969) $\$ 3.00$

No.31-The Undergraduate Library. Irene A Braden. (1970) $\$ 8.50$

No.32-Interlibrary Ioan Involving Academic Libraries. Sarah K. Thomson. (1970) $\$ 5.00$.

No.33-The Case for Faculty Status for Academic Librarians. Lewis C. Branscomb ed. (1970) $\$ 5.00$

No.34-Nonprint Media in Academic Libraries. Pearce S. Grove, ed. (1975) $\$ 10.00$

No. 35-Thomas Bray's Grand Design. Charles T. Laugher. (1973) $\$ 8.50$

No.36-The Shaping of American Library Education. Charles D. Churchwell. (1975) $\$ 8.50$

No.37-The Role of the Beginning Librarian in University Libraries. Ralph M. Edwards (1976). $\$ 6.50$.

No.38-Collective Bargaining in Higher Education. Millicent D. Abell, ed. (1976) $\$ 7.50$.

No.39-Libraries for Teaching, Libraries for Research: Essays for a Century. Richard D. Johnson, ed. (1977) \$12.50. 